\title{
Synthesis, antimicrobial and antimalarial activityof1, 4-benzothiazepine and pyrazolinederivatives incorporating carbazolemoiety
}

\author{
V. A. Kadnor ${ }^{1}$, S. N. Shelke ${ }^{2 *}$ \\ ${ }^{1}$ Department of Chemistry, A. C. S. College Satral, Rahuri, Ahmednagar, MS 413711, India \\ ${ }^{2}$ Department of Chemistry, S. S. G. M. College, Kopargaon, Ahmednagar, MS 423601, India
}

Received July 18, 2018; Revised August 30, 2018

\begin{abstract}
A series ofcarbazole-based 1,4-benzothiazepine and pyrazoline derivatives weresynthesized and the structures of the newly synthesized compoundswere confirmed by FT-IR, ${ }^{1} \mathrm{H}$ NMR, ${ }^{13} \mathrm{C}$ NMR and mass spectral studies. All new derivatives $\mathbf{4 ( a - f ) a n d ~} \mathbf{5 ( a - e ) w e r e ~ s c r e e n e d ~ f o r ~ t h e i r i n ~ v i t r o ~ a n t i m i c r o b i a l ~ a c t i v i t y , ~ a n d ~ a l s o ~ f o r ~ t h e i r ~ a n t i m a l a r i a l ~}$ activity.Compounds $\mathbf{4 a}, \mathbf{4 b}, \mathbf{4 d}, \mathbf{5 a}, \mathbf{5 b}$ and $\mathbf{5 c e x h i b i t e d p r o m i s i n g a n t i m i c r o b i a l ~ a n d ~ a n t i m a l a r i a l ~ a c t i v i t i e s ~ a s ~ c o m p a r e d ~}$ to positive control. Notably, compounds $\mathbf{4 a}, \mathbf{4 b a n d} \mathbf{4 d}$ showedexcellent antifungal activity against Penicillium $s p$.comparable to that of a standard drug.
\end{abstract}

Key words:Carbazole, 1,4-Benzothiazepine,Pyrazoline,Antimicrobial andantimalarial activities

\section{INTRODUCTION}

A large number of natural and synthetic carbazole derivatives have been reported to exhibit diverse biological activities such as antimicrobial $[1,2]$, antiviral [3], antimalarial [4] and potential application as pharmacological agents $[5,6]$. Recentlycarbazole-substitutedchalcone and its urea derivatives have been reported to exhibit antimicrobial, radical scavenger, cancer chemopreventive and polyphenol oxidase enzyme activities [7, 8]. Chalcones are also key precursors in the synthesis of many biologically important heterocyclic compounds such as benzothiazepines and pyrazolines.

Thiazepinesbelong to the important class of heterocyclic compoundsfor the synthesis of pharmaceutical agents, as well as biologically active compounds [9]. Benzothiazepinesplay an important role in drug discovery, as they show bioactivities such as anticonvulsant [10], endogenous natriuretic factors [11], potential central nervous system agents [12], antibiotics [13], antimicrobials [14], antihypertensive [15], antidiabetic [16] and cytotoxic agents [17].Novel carbazole assembled 1,4-thiazepine derivatives have been reported, which not only have significant antioxidant activities, but also exhibit remarkably selective cytotoxicity to carcinoma cell line HCT 116 [18]. Pyrazolines and their derivatives have been found to possess a wide spectrum of biological activities such as antimicrobial [19-22], antimalarial [23, 24], anti-inflammatory [25] and antioxidant [26].3-(substituted)-aryl-5-(9-methyl-3carbazole)-1 $H$-2-pyrazolines are reported as a novel class of anti-inflammatory and antioxidant agents

* To whom all correspondence should be sent:

E-mail: snshelke@yahoo.co.in

234
[27], thus literature survey reveals that carbazole is a useful starting material for pharmacologically important products.

Therefore, in continuation of our efforts to synthesize biologically active heterocyclic compounds $[28,29]$, herein we report the synthesis of carbazole-containing 1,4-benzothiazepineand pyrazolinederivatives with their antimicrobial and antimalarial activities.

\section{RESULTS AND DISCUSSION}

\section{Chemistry}

In view of the emerging biological importance of carbazole, we synthesized a series of carbazolechalcones and its corresponding 1,4benzothiazepine and pyrazolinederivatives from 3formyl-9-ethyl carbazole2 as shown in scheme1 on the hope of obtaining more antimicrobial and antimalarial agents. Thus, the starting compound 3formyl-9-ethylcarbazole $\mathbf{2}$ was prepared byVilsmeier-Haack formylation of carbazole1. 3formyl-9-ethylcarbazole 2 was obtainedbyClaisenSchmidt condensation with various substituted 2hydroxyacetophenones in ethanolic potassium hydroxide afforded carbazolechalcones 3 . The 1,4benzothiazepine4(a-f)derivatives were synthesized by Michael addition of 2-aminothiophenol to carbazolechalcones3in acetic acid and ethanol. Carbazolepyrazolines5(a-e)were prepared from the compounds 3 on treatment with hydrazine hydrate in ethanol and acetic acid, the reaction most likely takes place through the intervention of an appropriate $\alpha, \beta$-unsaturated hydrazone, which instantly cyclizes to give a pyrazoline ring, at reflux temperature cyclizing agent is acetic acid. 
V. A. Kadnor, S. N. Shelke: Synthesis, antimicrobial and antimalarial activity of 1, 4-benzothiazepine and ...

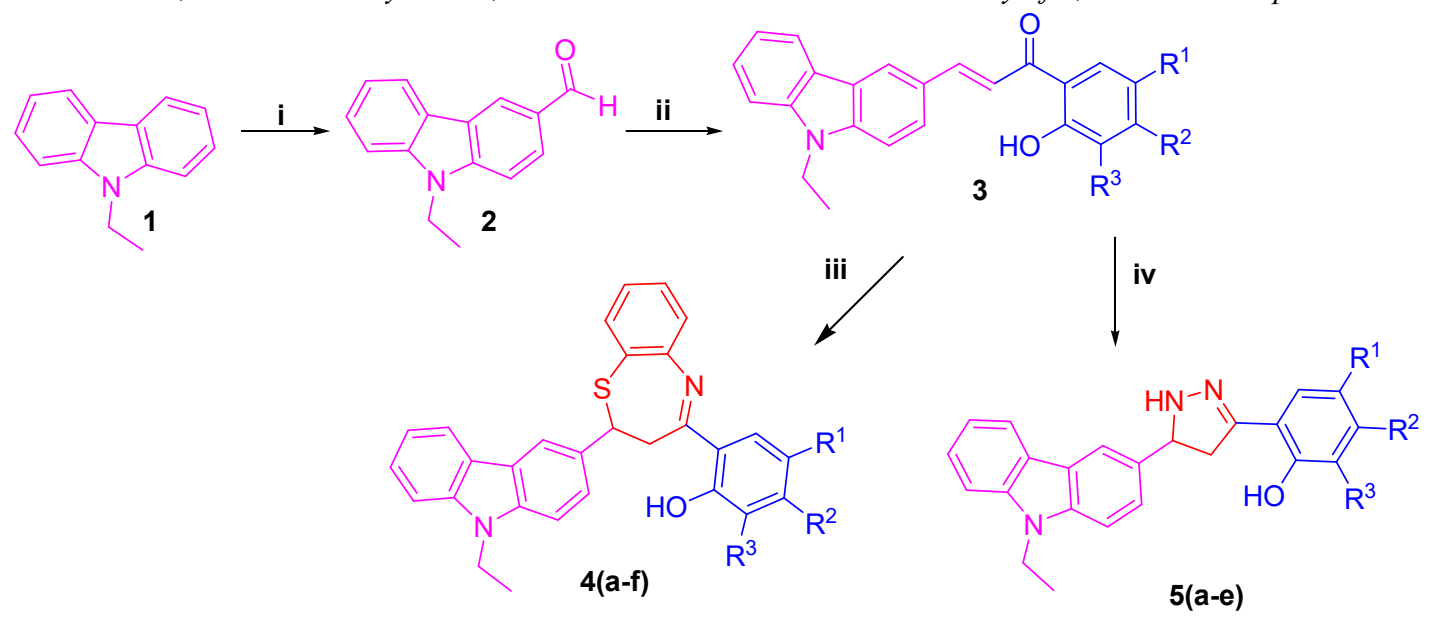

Scheme1. Reagents and conditions: (i) DMF, $\mathrm{POCl}_{3}, 80^{\circ} \mathrm{C}$, $4 \mathrm{~h}$ (ii) Substituted2-hydroxyacetophenones, $\mathrm{KOH}, \mathrm{EtOH}$, rt., 24-36 h. (iii) 2-Aminothiophenol, $\mathrm{AcOH}$, EtOH, Reflux, 8h. (iv) $\mathrm{NH}_{2} \mathrm{NH}_{2} \cdot \mathrm{H}_{2} \mathrm{O}$, EtOH, AcOH, reflux 6 h.

The structures of $\mathbf{4 ( a - f )}$ and $\mathbf{5 ( a - e ) ~ w e r e ~}$ confirmed by FT-IR, ${ }^{1} \mathrm{H}$ and ${ }^{13} \mathrm{C}$ NMR, and mass spectroscopic technique.For example, the infrared spectra of compounds 4(a-f) showed characteristic signals at 1688 and $3350 \mathrm{~cm}^{-1}$ for $\mathrm{C}=\mathrm{N}$ and hydroxyl group absorption, respectively.In general, three thiazepine protons of carbazole-based benzothiazepines showed similar patterns of signals in the ${ }^{1} \mathrm{H}$ NMR spectra. They displayed a doublet of a doublet at $\mathrm{C}_{17}$ for two protons and a triplet at $\mathrm{C}_{16}$ for one proton. The methine proton at $\mathrm{C}_{16}$ of the thiazepine nucleus resonates at around $\delta 3.25 \mathrm{ppm}$ as a triplet with coupling constant $(J)$ of nearly 12.6 $\mathrm{Hz}$. This signal is observed as a triplet instead of a doublet of a doublet because two $J$-values accidentally are the same and two inner lines of the quartet occur at the same point, appearing as a single line of double intensity [30]. The two methylene protons at $\mathrm{C}_{17}$ displayed two signals as a doublet of doublet at around $\delta 3.45 \mathrm{ppm}$ with coupling constantsof nearly $9.5 \mathrm{~Hz}$ and $3.8 \mathrm{~Hz}$ and a doublet of doublet at around $\delta 5.16 \mathrm{ppm}$ with coupling constants of nearly $9.4 \mathrm{~Hz}$ and $3.9 \mathrm{~Hz}$. The ${ }^{13} \mathrm{C}$ NMR spectrum of compounds $4(\mathbf{a}-\mathbf{f})$ showedaromatic carbon signals in the region of $108.68-157.89 \mathrm{ppm}$. In the mass spectrum in all cases, peaks corresponding to molecular ions were observed which confirmed their molecular weights.

IR spectra of the compounds 5(a-e) revealed a characteristic strong intensity band due to $-\mathrm{OH}$ and $-\mathrm{NH}$ stretching at 3668 and $3205 \mathrm{~cm}^{-}$ ${ }^{1}$ respectively, whilea pyrazoline $-\mathrm{C}=\mathrm{N}$ band was observed around $1614 \mathrm{~cm}^{-1}$. The ${ }^{1} \mathrm{H}$ NMR spectrum of these compounds exhibited an $\mathrm{ABX}$ pattern for the presence of two diastereotopic protons at $\mathrm{C}_{17}$ and one single proton at the $\mathrm{C}_{16}$ position. Asymmetric - $\mathrm{CH}$ proton displayed a triplet at $\delta$ $5.12 \mathrm{ppm}$ with $J=10.8 \mathrm{~Hz}$, whereas the pro-chiral methylene $\left(\mathrm{CH}_{2}\right)$ protons appeared as two characteristic doublets of a doublet at $\delta 3.16$ and $3.66 \mathrm{ppm}$ with $J=10.8$ and 5.7 Hzwhich indicates the magnetic non-equivalence of the two protons. According to the high resolution mass spectrum (HRMS) of the representative compound 5acalculated for $\mathrm{C}_{23} \mathrm{H}_{20} \mathrm{ON}_{3} \mathrm{Cl}_{2} \quad(\mathrm{M}+\mathrm{H})^{+}$ws 424.0981, found 424.0978.

\section{Antibacterial and antifungal evaluation}

The synthesized carbazole-assembled 1,4benzothiazepine4(a-f)and pyrazoline 5(ae)derivativeswere tested for their in vitro antimicrobial activity against two gram negative (Escherichia coli, Pseudomonas putida), two gram positive (Bacillus subtilis, Streptococcus lactis) bacterialstrains and three (Aspergillus niger, Penicillium sp., Candida albicans) fungal strains usingampicillin and greseofulvin as standard drugs, respectively.The inhibition zone diameters were measured in millimeters ( $\mathrm{mm}$ )andminimal inhibitory concentration (MIC) was expressed as $\mu \mathrm{g} / \mathrm{mL}$ of all synthesized compounds, the results obtained are enclosed in Table 1. Among the synthesized compounds, 4a, 4b, 4d,5a, 5b and 5ccould effectively inhibit the growth of most tested bacterial and fungal strains with considerable MIC $(\mu \mathrm{g} / \mathrm{mL})$ values. Carbazole-tethered 1,4benzothiazepines $\mathbf{4}(\mathbf{a}-\mathbf{f})$, three derivatives $4 a, 4 b$ and 4d exhibited a significant activity against P.putida with MIC valuesof 50,40 and $45 \mu \mathrm{g} / \mathrm{mL}$, respectively as compared with positive control. Three compounds $\mathbf{4 c}, \mathbf{4 e}$ and $\mathbf{4 f}$ also displayed moderate antibacterial activities $(65-100 \mu \mathrm{g} / \mathrm{mL})$ against all evaluated bacterial strains. Notably, compounds $\mathbf{4 a}, \mathbf{4 b}$ and $\mathbf{4 d}$ gave remarkable broader antifungal bioactive spectrum with MIC values in the range of $40-45 \mu \mathrm{g} / \mathrm{mL}$ against Penicillium $s p$. while two compounds $\mathbf{4 c}$ and4ehad satisfying activities against all screened fungal strains with 
V. A. Kadnor, S. N. Shelke: Synthesis, antimicrobial and antimalarial activity of 1, 4-benzothiazepine and ... considerable MIC values. It was found that carbazole pyrazolines5(a-e), compounds $\mathbf{5 a}, \mathbf{5 b}$ and 5cshowed strong activities $(45-65 \mu \mathrm{g} / \mathrm{mL})$ against gram positive $B$. subtilis and gram negative $P$. putida bacteria, while compounds $\mathbf{5 d}$ and $\mathbf{5 e}$ showedgood activities $(70-110 \mu \mathrm{g} / \mathrm{mL})$ against allfour bacterial strains as compared with standard drug ampicillin. As for antifungal activities, compound5a exhibited significant activity against Penicillium sp. and C. albicanswith MIC valuesof 55 and $60 \mu \mathrm{g} / \mathrm{mL}$, respectively, while $\mathbf{5 b}, \mathbf{5 c}, \mathbf{5 d}$ and 5e showed moderate activities (70-100 $\mu \mathrm{g} / \mathrm{mL}$ )against all testedfungal strainscompared to that of standard drug greseofulvin.

\section{Antimalarial activity}

The synthesized compounds $\mathbf{4}$ and $\mathbf{5}$ were also screened for theirin vitro antimalarial activity against Plasmodium falciparumstrain using chloroquine and quinine as reference drugs. The mean $\mathrm{IC}_{50}(\mu \mathrm{g} / \mathrm{mL})$ values of the test compounds against the test microbe are presented in Table 2.The results revealed that the majority of the synthesized compounds showed significant degrees of inhibition against $P$. falciparum as compared with positive control quinine than that of chloroquine. Carbazole benzothiazepine derivatives 4(a-f), 4a and 4b showed moderate growth inhibition activities with $\mathrm{IC}_{50}$ values of 0.75 and $0.80 \mu \mathrm{g} / \mathrm{mL}$ as compared with standard drug quinine, while compounds $\mathbf{4 c}, \mathbf{4 d}, \mathbf{4 e}$ and $\mathbf{4 f}$ showed the lowest inhibition activities against $P$. falciparum comparable to that of reference compounds. The carbazole-pyrazoline derivatives 5(a-e), compound 5a exhibiteda good antimalarial spectrum with $\mathrm{IC}_{50}$ value of $0.56 \mu \mathrm{g} / \mathrm{mL}$ as compared with standard drug quinine, the remaining four compounds $\mathbf{5 b}, \mathbf{5 c}, \mathbf{5 d}$ and 5eshowed considerable inhibition activities withIC $_{50}$ values in the range of $0.76-1.25 \mu \mathrm{g} / \mathrm{mL}$.

\section{CONCLUSION}

As structure-activity relationships (SAR) of all compounds were taken into account, it was observed that compounds $4 \mathbf{a}, \mathbf{4 b}, \mathbf{4 d}, \mathbf{5 a}, \mathbf{5 b}$ and 5chaving electron withdrawing groups like chloro and bromo substituents on the phenyl ring showed excellent potential of antibacterial and antifungal activities. The antimalarial evaluation of $\mathbf{4 ( a - f )}$ and 5(a-e)revealed that, as the electronegativity nature of the substituents attached to an aromatic ring decreased, activity also decreased. Two derivatives4cand $\mathbf{5 d}$ containing electron releasing methyl and electron withdrawing chlorine groupattached to phenyl ring were able to display moderate growth inhibitory activity against all tested microorganisms. In addition, carbazole derivatives4eand 5econtaining methyl and methoxy group on the phenyl ring also inhibited thegrowth of the tested bacterial and fungal strains. Furthermore, compound4f without substituent in the phenyl ring showed the lowest activities against all tested bacterial, fungal and antimalarial strains. In general, all synthesized compounds $\mathbf{4}$ and $\mathbf{5}$ exhibited only moderate antimalarial activity $\mathrm{IC}_{50}$ values ranging $0.56-1.25 \mu \mathrm{g} / \mathrm{mL}$.High potency and promising antimicrobial and antimalarial activity of the newly synthesized compounds $\mathbf{4}(\mathbf{a}-\mathbf{f})$ and $\mathbf{5 ( a -}$ e)suggest that these compounds could serve as good leads for further optimization and development.

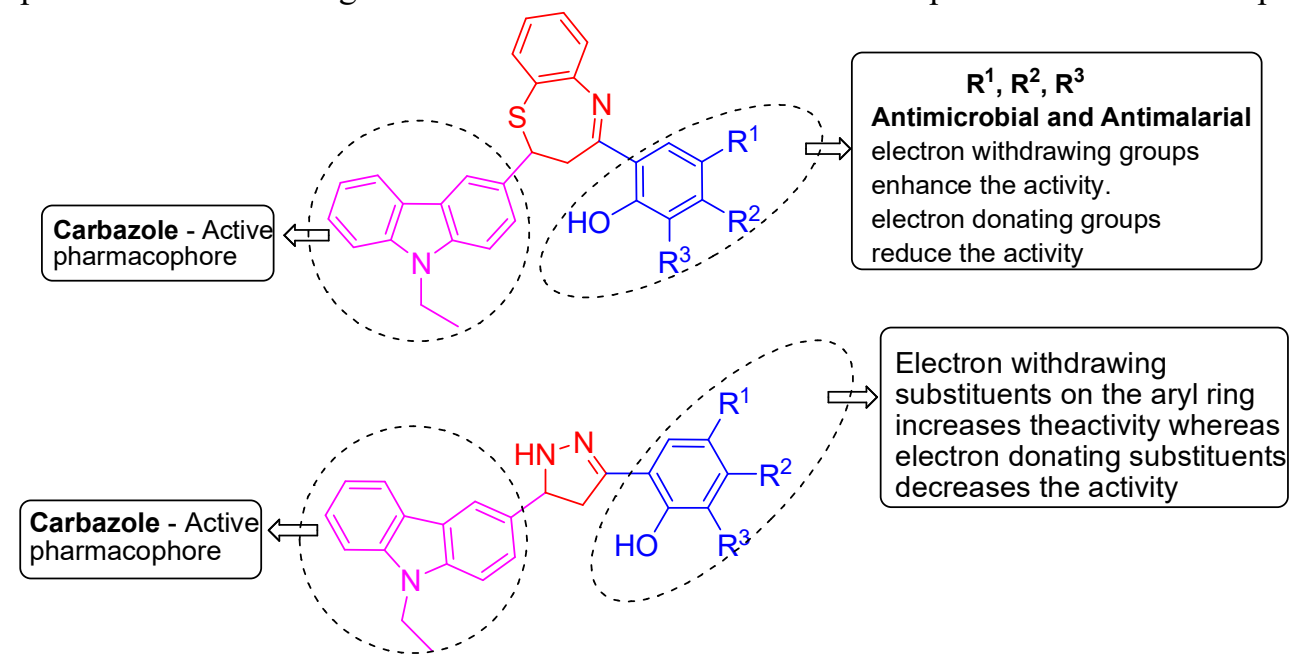

Figure 1. The structure- activity relationship in the target compounds 
V. A. Kadnor, S. N. Shelke: Synthesis, antimicrobial and antimalarial activity of 1, 4-benzothiazepine and ... Table 1.Antimicrobial activities of the synthesized compounds $\mathbf{4}$ and $\mathbf{5}$ against pathological organisms expressed

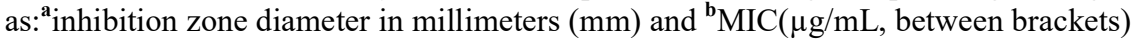

\begin{tabular}{|c|c|c|c|c|c|c|c|}
\hline \multirow{3}{*}{ Compounds } & \multicolumn{7}{|c|}{ Microorganisms } \\
\hline & \multicolumn{2}{|c|}{ Gram negative bacteria } & \multicolumn{2}{|c|}{ Gram positive bacteria } & \multicolumn{3}{|c|}{ Fungi } \\
\hline & E. coli & P. putida & B. subtilis & S. lactis & A. niger & $\begin{array}{l}\text { Penicillium } \\
\text { sp. }\end{array}$ & C. albicans \\
\hline $4 \mathrm{a}$ & $16(50)$ & $18(50)$ & $15(100)$ & $20(110)$ & $17(80)$ & $14(45)$ & $12(100)$ \\
\hline $4 b$ & $16(65)$ & $17(40)$ & $16(80)$ & $16(80)$ & $18(100)$ & $14(40)$ & $12(130)$ \\
\hline $4 c$ & $17(80)$ & $16(65)$ & $15(80)$ & 19(100) & $17(65)$ & $13(100)$ & $11(100)$ \\
\hline $4 d$ & $17(50)$ & $18(45)$ & $16(100)$ & $15(110)$ & $17(100)$ & $14(40)$ & $12(80)$ \\
\hline $4 \mathrm{e}$ & $15(80)$ & $14(80)$ & $12(65)$ & $17(80)$ & $14(80)$ & $11(80)$ & $11(100)$ \\
\hline $4 \mathrm{f}$ & $14(100)$ & $13(80)$ & $13(100)$ & $13(100)$ & $12(65)$ & $12(80)$ & $10(80)$ \\
\hline $5 a$ & $15(80)$ & $16(45)$ & $17(50)$ & $18(45)$ & $17(80)$ & $12(55)$ & $12(60)$ \\
\hline $5 b$ & $14(80)$ & $16(50)$ & $17(50)$ & $16(50)$ & $16(100)$ & $12(70)$ & $12(80)$ \\
\hline $5 c$ & 14(100) & $15(65)$ & $16(45)$ & $14(65)$ & $16(100)$ & 11(90) & 11(90) \\
\hline $5 d$ & $15(90)$ & $14(80)$ & $16(70)$ & $18(80)$ & 13(90) & $11(100)$ & $11(80)$ \\
\hline $5 \mathrm{e}$ & 11(110) & $12(100)$ & 11(100) & $15(80)$ & $12(100)$ & $09(100)$ & $11(80)$ \\
\hline Ampicillin & $24(25)$ & $20(25)$ & $19(25)$ & $22(25)$ & .. & ... & $\ldots$ \\
\hline Greseofulvin & $\ldots$ & ... & $\ldots$ & ... & $24(25)$ & $14(25)$ & $14(25)$ \\
\hline $\begin{array}{c}\text { Control } \\
(1 \% \text { DMSO })\end{array}$ & NA & NA & NA & NA & NA & NA & NA \\
\hline
\end{tabular}

Table 2.Substitution pattern andin vitro antimalarial activity of the target compounds $\mathbf{4}$ and $\mathbf{5}$

\begin{tabular}{ccccc}
\hline & & & $\mathrm{R}^{3}$ & P. falciparum \\
\cline { 5 - 5 } Compounds & $\mathrm{R}^{1}$ & $\mathrm{R}^{2}$ & $\mathrm{Cl}$ & 0.75 \\
$4 \mathrm{a}$ & $\mathrm{Cl}$ & $\mathrm{H}$ & $\mathrm{H}$ & 0.80 \\
$4 \mathrm{~b}$ & $\mathrm{Cl}$ & $\mathrm{H}$ & $\mathrm{H}$ & 0.85 \\
$4 \mathrm{c}$ & $\mathrm{Cl}$ & $\mathrm{CH}_{3}$ & $\mathrm{H}$ & 0.90 \\
$4 \mathrm{e}$ & $\mathrm{Br}$ & $\mathrm{H}$ & $\mathrm{H}$ & 1.10 \\
$4 \mathrm{f}$ & $\mathrm{CH}_{3}$ & $\mathrm{H}$ & $\mathrm{H}$ & 1.30 \\
$5 \mathrm{a}$ & $\mathrm{H}$ & $\mathrm{H}$ & $\mathrm{H}$ & 0.56 \\
$5 \mathrm{~b}$ & $\mathrm{Cl}$ & $\mathrm{Cl}$ & $\mathrm{H}$ & 0.76 \\
$5 \mathrm{c}$ & $\mathrm{Cl}$ & $\mathrm{H}$ & $\mathrm{H}$ & 0.88 \\
$5 \mathrm{~d}$ & $\mathrm{Br}$ & $\mathrm{H}$ & $\mathrm{H}$ & 1.20 \\
$5 \mathrm{e}$ & $\mathrm{Cl}$ & $\mathrm{CH}$ & $\mathrm{H}$ & 1.25 \\
Quinine & $\mathrm{H}$ & $\mathrm{OCH}_{3}$ & --- & 0.268 \\
Chloroquine & --- & --- & -- & 0.020 \\
\hline
\end{tabular}




\section{A. Kadnor, S. N. Shelke: Synthesis, antimicrobial EXPERIMENTAL}

The recorded melting points were determined in an open capillary and are uncorrected. IR spectra were recorded on a PerkinElmer Fourier-transform infrared (FTIR) spectrophotometer with ATR. The ${ }^{1} \mathrm{H}$ NMRand ${ }^{13} \mathrm{C}$ NMR spectrawere recorded on a Bruker Avance II (400 MHz) and Bruker (125 $\mathrm{MHz}$ ) spectrometer respectively, using TMS as internal standard.Mass spectra were recorded on a Waters, Q-Tof micromass spectrometer andhighresolution mass spectra (ESI) were recorded on a Thermo scientific Q-Exactive, Accela 1250 pump. The thin layer chromatography (TLC) was carried out on precoated silica gel aluminum plates to check compounds purity. Starting compound 9ethyl-9H-carbazole is of Sigma Aldrich make.

In vitro antimicrobial assay

The antimicrobial activity was evaluated by the agar well diffusion method [31]. The activity was determined by measuring the diameter of inhibition zone (in $\mathrm{mm}$ ). The samples of the tested compound concentrations ( $50 \mu \mathrm{L}, 1 \mathrm{mg} / \mathrm{mL})$ were loaded into wells on the plates. All solutions were prepared in DMSO, and pure DMSO was loaded as a control. The plates were incubated at $37^{\circ} \mathrm{C}$ for $1-5$ days and then were examined for the formation of inhibition zone. Each inhibition zone was measured three times to get an average value. The test was performed three times for each bacterium culture [32].

\section{Minimal inhibitory concentration (MIC) measurement}

The potato dextrose broths and microorganism susceptibility tests in nutrient media were used for the determination of MIC. Tested compounds stock $1000 \mu \mathrm{g} / \mathrm{mL}$ solutions, ampicillin and greseofulvin were prepared in DMSO followed by dilutions to 250-25 $\mu \mathrm{g} / \mathrm{mL}$ concentrations. Inoculated microorganism suspensions were incubated at $37^{\circ} \mathrm{C}$ for 1-5 days for MIC determination.

\section{Antimalarial activity}

A stock solution of $5 \mathrm{mg} / \mathrm{mL}$ of each of the test samples, as well as standards was prepared in DMSO and subsequent dilutions were prepared with the culture medium. The diluted samples in 20 $\mu \mathrm{L}$ volumes were added to the test wells so as to obtain final concentrations (at five-fold dilutions) ranging between 0.4 and $100 \mu \mathrm{g} / \mathrm{mL}$ in duplicate well containing parasitized cell preparation. The in vitro antimalarial assay was carried out in 96 well plates according to the micro assay protocol with minor modifications [33]. The cultures of $P$. falciparumstrain were maintained in a medium of
RPMI 1640 supplemented with 25 mM HEPES, $1 \%$ D-glucose, $0.23 \%$ sodium bicarbonate and $10 \%$ heat-inactivated human serum. The asynchronous parasites of $P$. falciparum were synchronized after $5 \%$ D-sorbitol treatment to obtain only the ring stage parasitized cells. For carrying out the assay, an initial ring stage parasitaemia of $0.8-1.5 \%$ at $3 \%$ haematocrit in a total volume of $200 \mu \mathrm{L}$ of medium RPMI-1640 was determined by Jaswant Singh Bhattacharya (JSB) staining[34]to assess the percent parasitaemia (rings) and uniformlymaintained with $50 \%$ RBCs $\left(\mathrm{O}^{+v e}\right)$. The culture plates were incubated at $37^{\circ} \mathrm{C}$ in a candle jar. After 36-40 h of incubation, thin blood smears from each well were prepared stained with JSB stain. The slides were microscopically observed to record maturation of the ring stage parasites into trophozoites and schizonts in the presence of different concentrations of the test agents. The test concentrations which inhibited the complete maturation in to schizonts were recorded as the minimum inhibitory concentrations (MIC). Chloroquine and quinine were used as the reference drugs.

\section{General procedure for the synthesis of 3-formyl-9- ethylcarbazole(2)}

9-ethyl carbazole 1 (1.95 g, $10 \mathrm{mmol})$ was dissolved in dry DMF $(20 \mathrm{~mL})$ under anhydrous conditions. It was cooled to $0^{\circ} \mathrm{C}$, and $\mathrm{POCl}_{3}(1.89$ $\mathrm{mL}$ ) was added dropwise and stirring continued for $4 \mathrm{~h}$ at $80^{\circ} \mathrm{C}$. Completion of reaction was monitored by TLC.The reaction mass was poured over crushed ice, neutralized with $\mathrm{NaHCO}_{3}$, the white colored precipitate was filtered off and purified through recrystallization using ethyl alcohol to afford compound 2 .

\section{General procedure for the synthesis of benzothiazepine derivatives 4(a-f)}

Chalcone 3 (2 mmol) was dissolved in a minimum quantity of ethanol. To this, 2aminothiophenol $(2 \mathrm{mmol})$ was added and the resulting reaction mixture was refluxed at $60-70{ }^{\circ} \mathrm{C}$ for $3 \mathrm{~h}$. Then, the mixture was acidified with 5-6 drops of glacial acetic acid and heating was continued for further 4-5 h. After completion of the reaction (monitored by TLC), the reaction mixture was cooled and poured over crushed ice. The obtained solid was filtered and purified by recrystallization from methanol to afford compounds4(a-f).

2,4-Dichloro-6-((E)-2-(9-ethyl-9H-carbazol-3yl)-2,3-dihydrobenzo[b] [1,4] thiazepin-4yl)phenol

(4a): Light yellow colored solid; Yield $(69 \%) ; \mathrm{R}_{\mathrm{f}}=$ 0.54 (6\% ethylacetate in $n$-hexane);m. p. 222- 
V. A. Kadnor, S. N. Shelke: Synthesis, antimicrobial and antimalarial activity of 1, 4-benzothiazepine and ... $223^{\circ} \mathrm{C}$; IR $\tilde{v}_{\max } / \mathrm{cm}^{-1}: 3559(\mathrm{OH}), 2976(\mathrm{CH}), 1593$ $(\mathrm{C}=\mathrm{N}) ;{ }^{1} \mathrm{H}$ NMR $\left(\mathrm{CDCl}_{3}\right) \delta / \mathrm{ppm}: 1.42(\mathrm{t}, 3 \mathrm{H}$, $\left.J=6.4 \mathrm{~Hz}, \mathrm{CH}_{3}\right), 3.25$ (t, $1 \mathrm{H}, J=12.5 \mathrm{~Hz}$, thiazepine ring), $3.41(\mathrm{dd}, 1 \mathrm{H}, J=9.5 \& 3.8 \mathrm{~Hz}$, thiazepine ring), $4.40\left(\mathrm{q}, 2 \mathrm{H}, J=6.7 \mathrm{~Hz}, \mathrm{~N}-\mathrm{CH}_{2}\right), 5.36(\mathrm{dd}, 1 \mathrm{H}$, $J=9.2 \& 3.8 \mathrm{~Hz}$, thiazepine ring), 7.22-7.30 (m, $2 \mathrm{H}$, Ar-H), 7.35-7.42 (m, 3H, Ar-H), 7.48-7.55 (m, 4H, Ar-H), 7.70- 8.05 (m, 4H, Ar-H), 15.92 (s, 1H, Ar$\mathrm{OH}),{ }^{13} \mathrm{C}$ NMR $\left(\mathrm{CDCl}_{3}\right) \delta / \mathrm{ppm}: 13.84,37.68$, $60.99,108.68,108.86,117.85,119.08,119.54$, $120.49,122.40,122.63,122.97,123.84,124.00$, $125.34,125.74,126.08,126.62,127.22,130.09$, $133.12,133.56,135.44,139.71,140.42,147.48$, 157.89, 172.25; MS $(m / z): 517(\mathrm{M}+\mathrm{H})^{+}$.

4-Chloro-2-((E)-2-(9-ethyl-9H-carbazol-3-yl)2,3-dihydrobenzo[b] [1,4]thiazepin-4-yl)phenol

(4b): Light yellow colored solid; Yield (70\%); $\mathrm{R}_{\mathrm{f}}=$ 0.52 (6\% ethylacetate in n-hexane);m. p. 226$228^{\circ} \mathrm{C}$; IR $\tilde{v}_{\max } / \mathrm{cm}^{-1}$ : $3376(\mathrm{OH}), 3055(\mathrm{CH})$, 1611 $(\mathrm{C}=\mathrm{N}) ;{ }^{1} \mathrm{H}$ NMR $\left(\mathrm{CDCl}_{3}\right) \delta / \mathrm{ppm}: 1.43(\mathrm{t}, 3 \mathrm{H}$, $\left.J=7.0 \mathrm{~Hz}, \mathrm{CH}_{3}\right), 3.24(\mathrm{t}, 1 \mathrm{H}, J=12.6 \mathrm{~Hz}$, thiazepine ring), $3.42(\mathrm{dd}, 1 \mathrm{H}, J=8.8 \& 4.5 \mathrm{~Hz}$, thiazepine ring), 4.37 (q, $\left.2 \mathrm{H}, J=7.0 \mathrm{~Hz}, \mathrm{~N}-\mathrm{CH}_{2}\right), 5.32(\mathrm{dd}, 1 \mathrm{H}$, $J=8.2 \& 4.4 \mathrm{~Hz}$, thiazepine ring), 7.03 (m, 1H, ArH), 7.22-7.28 (m, 3H, Ar-H), 7.32-7.37 (m, 3H, ArH), 7.40-7.46 (m, 2H, Ar-H), 7.51-7.53 (m, 2H, Ar$\mathrm{H})$, 7.69-8.06 (m, 3H, Ar-H), 14.63 (s, 1H, Ar$\mathrm{OH}) ;{ }^{13} \mathrm{C} \mathrm{NMR}\left(\mathrm{CDCl}_{3}\right) \delta / \mathrm{ppm}: 14.19,37.75$, $60.80,108.16,108.60,108.83,109.25,110.47$, $119.80,120.02,120.76,121.23,122.10,123.08$, $123.31,124.94,126.04,126.82,127.48,133.30$, $137.03,138.44,140.98,141.49,142.39,144.25$, $145.45, \quad 168.95, \quad 169.25, \quad 175.02 ; \mathrm{MS}$ $(\mathrm{m} / \mathrm{z}): 483(\mathrm{M}+\mathrm{H})^{+}$.

4-Chloro-2-((E)-2-(9-ethyl-9H-carbazol-3-yl)2,3-dihydrobenzo[b] [1,4] thiazepin-4-yl)-5-

methylphenol (4c): Light yellow colored solid; Yield $(68 \%) ; \mathrm{R}_{\mathrm{f}}=0.58(6 \%$ ethylacetate in $\mathrm{n}$ hexane);m. p. $196-197^{\circ} \mathrm{C}$; IR $\tilde{v}_{\max } / \mathrm{cm}^{-1}: 3550$ (OH), $2935(\mathrm{CH}), 1688(\mathrm{C}=\mathrm{N}){ }^{1} \mathrm{H}$ NMR $\left(\mathrm{CDCl}_{3}\right) \delta$ / ppm: $1.48\left(\mathrm{t}, 3 \mathrm{H}, J=7.0 \mathrm{~Hz}, \mathrm{CH}_{3}\right), 2.35$ (s, 3H, Ar$\left.\mathrm{CH}_{3}\right), 3.20$ (t, $1 \mathrm{H}, J=12.6 \mathrm{~Hz}$, thiazepine ring), 3.44 (dd, $1 \mathrm{H}, J=8.8 \& 4.5 \mathrm{~Hz}$, thiazepine ring), 4.39 (q, $\left.2 \mathrm{H}, J=7.0 \mathrm{~Hz}, \mathrm{~N}-\mathrm{CH}_{2}\right), 5.30(\mathrm{dd}, 1 \mathrm{H}, J=7.8 \& 4.4$ $\mathrm{Hz}$, thiazepine ring), 7.05 (m, 1H, Ar-H), 7.20-7.29 (m, 2H, Ar-H), 7.33-7.42 (m, 3H, Ar-H), 7.40-7.48 (m, 2H, Ar-H), 7.55-7.65 (m, 2H, Ar-H), 7.73-7.85 (m, 1H, Ar-H), 8.05-8,10 (m, 2H, Ar-H), 14.60 (s, $1 \mathrm{H}, \mathrm{Ar}-\mathrm{OH}) ;{ }^{13} \mathrm{C} \mathrm{NMR}\left(\mathrm{CDCl}_{3}\right) \delta / \mathrm{ppm}: 13.74$, $37.50,60.85,108.66,108.83,117.77,119.25$, $119.58,120.39,122.55,122.65,122.90,123.80$, $124.10,125.25,125.72,126.23,126.68,127.49$, $130.08,133.17,133.47,135.49,139.75,140.48$, 147.40, 157.85, 170.85; MS $(\mathrm{m} / \mathrm{z}): 497(\mathrm{M}+\mathrm{H})^{+}$.

4-Bromo-2-((E)-2-(9-ethyl-9H-carbazol-3-yl)2,3-dihydrobenzo[b] [1,4] thiazepin-4-yl)phenol

(4d): Light yellow colored solid; Yield $(71 \%) ; \mathrm{R}_{\mathrm{f}}=$ $0.50(6 \%$ ethylacetate in n-hexane);m. p. 188$189^{\circ} \mathrm{C}$; IR $\tilde{v}_{\max } / \mathrm{cm}^{-1}: 3545(\mathrm{OH}), 2935(\mathrm{CH}), 1688$ $(\mathrm{C}=\mathrm{N}) ;{ }^{1} \mathrm{H}$ NMR $\left(\mathrm{CDCl}_{3}\right) \delta / \mathrm{ppm}: 1.45(\mathrm{t}, 3 \mathrm{H}$, $\left.J=7.3 \mathrm{~Hz}, \mathrm{CH}_{3}\right), 3.28(\mathrm{t}, 1 \mathrm{H}, J=12.3 \mathrm{~Hz}$, thiazepine ring), $3.45(\mathrm{dd}, 1 \mathrm{H}, J=8.9 \& 4.2 \mathrm{~Hz}$, thiazepine ring), 4.32 (q, 2H, J=7.1 Hz, N-CH $), 5.30(\mathrm{dd}, 1 \mathrm{H}$, $J=8.7 \& 4.3 \mathrm{~Hz}$, thiazepine ring), 7.05 (m, 1H, ArH), 7.20-7.29 (m, 3H, Ar-H), 7.34-7.38 (m, 3H, Ar$\mathrm{H})$, 7.43-7.49 (m, 2H, Ar-H), 7.55-7.63 (m, 2H, Ar$\mathrm{H})$, 7.70-8.09 (m, 3H, Ar-H), 14.33 (s, 1H, Ar$\mathrm{OH}) ;{ }^{13} \mathrm{C}$ NMR $\left(\mathrm{CDCl}_{3}\right) \delta / \mathrm{ppm}: 13.79,37.59$, 60.89 , 108.62, 108.81, 117.88, 119.07, 119.52, $120.44,122.47,122.68,122.92,123.89,124.09$, $125.37,125.72,126.06,126.63,127.21,130.08$, $133.28,133.59,135.49,139.72,140.48,147.41$, $157.75,172.85 ; \mathrm{MS}(\mathrm{m} / z): 527(\mathrm{M}+\mathrm{H})^{+}$.

2-((E)-2-(9-ethyl-9H-carbazol-3-yl)-2,3-

dihydrobenzo[b][1,4]thiazepin-4-yl)-4-

methylphenol (4e):Light yellow colored solid; Yield $(69 \%) ; \mathrm{R}_{\mathrm{f}}=0.56(6 \%$ ethylacetate in $\mathrm{n}$-hexane);m. p. $215-216^{\circ} \mathrm{C}$; IR $\tilde{v}_{\max } / \mathrm{cm}^{-1}: 3363(\mathrm{OH}), 2973$ (CH), $1594(\mathrm{C}=\mathrm{N}) ;{ }^{1} \mathrm{H}$ NMR $\left(\mathrm{CDCl}_{3}\right) \delta / \mathrm{ppm}: 1.44$ $\left(\mathrm{t}, 3 \mathrm{H}, J=7.0 \mathrm{~Hz}, \mathrm{CH}_{3}\right), 1.55\left(\mathrm{~s}, 3 \mathrm{H}, \mathrm{Ar}-\mathrm{CH}_{3}\right), 3.23$ (t, $1 \mathrm{H}, J=12.6 \mathrm{~Hz}$, thiazepine ring), $3.42(\mathrm{dd}, 1 \mathrm{H}$, $J=8.8 \& 4.5 \mathrm{~Hz}$, thiazepine ring), 4.37 (q, $2 \mathrm{H}, J=7.0$ $\left.\mathrm{Hz}, \mathrm{N}-\mathrm{CH}_{2}\right), 5.33$ (dd, $1 \mathrm{H}, J=7.8$ \& $4.4 \mathrm{~Hz}$, thiazepine ring), $7.01(\mathrm{~m}, 1 \mathrm{H}, \mathrm{Ar}-\mathrm{H}), 7.25-7.27(\mathrm{~m}$, 3H, Ar-H), 7.32-7.40 (m, 3H, Ar-H), 7.42-7.44 (m, 2H, Ar-H), 7.45-7.51 (m, 2H, Ar-H), 7.53-7.70 (m, 1H, Ar-H), 8.02-8.06 (m, 2H, Ar-H), 14.59 (s, 1H, Ar-OH $) ;{ }^{13} \mathrm{C}$ NMR $\left(\mathrm{CDCl}_{3}\right) \delta / \mathrm{ppm:} \mathrm{13.78,} \mathrm{37.58,}$ $60.87,108.65,108.80,117.87,119.04,119.58$, $120.49,122.44,122.67,122.96,123.88,124.06$, $125.39,125.70,126.03,126.69,127.29,130.09$, $133.27,133.57,135.48,139.70,140.44,147.43$, 157.72, 172.80; MS $(\mathrm{m} / \mathrm{z}): 463(\mathrm{M}+\mathrm{H})^{+}$.

2-((E)-2-(9-ethyl-9H-carbazol-3-yl)-2,3dihydrobenzo $[b][1,4]$ thiazepin-4-yl)phenol $\quad(4 f)$ : Light yellow colored solid; Yield $(68 \%) ; \mathrm{R}_{\mathrm{f}}=0.55$ ( $6 \%$ ethylacetate in n-hexane);m. p. $226-227^{\circ} \mathrm{C}$; IR $\tilde{v}_{\max } / \mathrm{cm}^{-1}$ : $3555(\mathrm{OH}), 2935(\mathrm{CH}), 1688(\mathrm{C}=\mathrm{N}){ }^{1}{ }^{1} \mathrm{H}$ NMR $\left(\mathrm{CDCl}_{3}\right) \delta / \mathrm{ppm}: 1.28(\mathrm{t}, 3 \mathrm{H}, J=7.2 \mathrm{~Hz}$, $\left.\mathrm{CH}_{3}\right), 3.12(\mathrm{t}, 1 \mathrm{H}, \mathrm{J}=12.8 \mathrm{~Hz}$, thiazepine ring), 3.65 (dd, $1 \mathrm{H}, J=9.4 \& 3.7 \mathrm{~Hz}$, thiazepine ring), 4.41 (q, $\left.2 \mathrm{H}, J=6.8 \mathrm{~Hz}, \mathrm{~N}-\mathrm{CH}_{2}\right), 5.45(\mathrm{dd}, 1 \mathrm{H}, J=9.4 \& 3.9$ $\mathrm{Hz}$, thiazepine ring), 6.95-6.99 (m, 2H, Ar-H), 7.18 (m, 1H, Ar-H), 7.29 (m, 1H, Ar-H), 7.38-7.45 (m, 4H, Ar-H), 7.53-7.64 (m, 4H, Ar-H), 7.91 (m, 3H, Ar-H), 14.32 (s, 1H, Ar-OH); ${ }^{13} \mathrm{C} \mathrm{NMR}\left(\mathrm{CDCl}_{3}\right) \delta /$ ppm: 13.74, 37.48, 60.92, 108.58, 108.83, 117.81, $119.06,119.53,120.45,122.42,122.67,122.90$, $123.80,124.08,125.35,125.74,126.07,126.65$, $127.20,130.07,133.10,133.57,135.46,139.73$, $140.47, \quad 147.42, \quad 157.80, \quad 172.23 ; \mathrm{MS}$ $(\mathrm{m} / z): 449(\mathrm{M}+\mathrm{H})^{+}$. 
V. A. Kadnor, S. N. Shelke: Synthesis, antimicrobial and antimalarial activity of 1, 4-benzothiazepine and ...

\section{General procedure for the synthesis of pyrazoline derivatives $5(a-e)$}

Chalcone3 (2 mmol)was dissolved in ethanol $(15 \mathrm{~mL})$ under stirring. To this reaction mixture, 0.5 $\mathrm{mL}$ of hydrazine hydrate and $0.2 \mathrm{~mL}$ of acetic acid was added. The reaction mixture was heated at reflux temperature for $6 \mathrm{~h}$. Completion of reaction was monitored by TLC. Thereaction mixture was cooled to room temperature. Then slowly $15 \mathrm{~mL}$ of cold water were added to the flask, the white solid obtained was washed with cold water several times.The crude compounds were recrystallizedfromethanol to afford the target compounds 5(a-e).

4,5-Dichloro-2-(5-(9-ethyl-9H-carbazol- 239 3-yl)-4,5-dihydro-1H-pyrazol-3-yl)phenol

$(5 a)$ : White colored solid; Yield $(65 \%) ; \mathrm{R}_{\mathrm{f}}=0.48$ ( $6 \%$ ethylacetate in n-hexane);m. p. $155-156^{\circ} \mathrm{C}$; IR $\tilde{\mathrm{v}}_{\max } / \mathrm{cm}^{-1}: 3668(\mathrm{OH}), 3205(\mathrm{NH}), 3051(\mathrm{CH})$, $1614(\mathrm{C}=\mathrm{N}) ;{ }^{1} \mathrm{H} \mathrm{NMR}\left(\mathrm{CDCl}_{3}\right) \delta / \mathrm{ppm}: 1.36(\mathrm{t}$, $\left.3 \mathrm{H}, J=7.5 \mathrm{~Hz}, \mathrm{CH}_{3}\right), 3.16(\mathrm{dd}, 1 \mathrm{H}, J=10.7 \mathrm{~Hz} \& 5.9$ $\mathrm{Hz}$, pyrazoline ring), $3.65(\mathrm{dd}, 1 \mathrm{H}, J=10.7 \& 5.9 \mathrm{~Hz}$, pyrazoline ring), 4.43 (q, 2H, $J=7.5 \mathrm{~Hz}, \mathrm{~N}-\mathrm{CH}_{2}$ ), $5.12(\mathrm{t}, 1 \mathrm{H}, J=10.7 \mathrm{~Hz}$, pyrazoline ring), 7.15-7.35 (m, 3H, Ar-H), 7.40-7.55 (m, 4H, Ar-H), 8.01 (m, 2H, Ar-H), 8.13 (m, 1H, NH), 12.02 (s, 1H, Ar$\mathrm{OH}) ;{ }^{13} \mathrm{C}$ NMR $\left(\mathrm{CDCl}_{3}\right) \delta / \mathrm{ppm}: 13.82,37.67$, $41.70,63.62,108.67,109.03,118.25,118.65$, $119.10,120.53,122.05,122.54,123.22,123.58$, $123.77,125.48, \quad 126.08, \quad 129.85,131.72, \quad 139.76$, 140.76, 152.26; HRMS (ESI): calculated for $\mathrm{C}_{23} \mathrm{H}_{20} \mathrm{ON}_{3} \mathrm{Cl}_{2}(\mathrm{M}+\mathrm{H})^{+} 424.0981$, found 424.0978 .

4-Chloro-2-(5-(9-ethyl-9H-carbazol-3-yl)-4,5dihydro-1H-pyrazol-3-yl)phenol (5b):White colored solid; Yield $(69 \%) ; \mathrm{R}_{\mathrm{f}}=0.52 \quad(6 \%$ ethylacetate in n-hexane);m. p. $141-142^{\circ} \mathrm{C}$; IR $\tilde{v}_{\max } /$ $\mathrm{cm}^{-1}$ : $3363(\mathrm{OH}), 3055(\mathrm{NH}), 2950(\mathrm{CH}), 1593$ $(\mathrm{C}=\mathrm{N}) ;{ }^{1} \mathrm{H} \mathrm{NMR}\left(\mathrm{CDCl}_{3}\right) \delta / \mathrm{ppm}: 1.35(\mathrm{t}, 3 \mathrm{H}$, $\left.J=8.5 \mathrm{~Hz}, \mathrm{CH}_{3}\right), 3.18$ (dd, $1 \mathrm{H}, J=12.5 \mathrm{~Hz} \& 6.5 \mathrm{~Hz}$, pyrazoline ring), $3.69(\mathrm{dd}, 1 \mathrm{H}, J=12.5 \& 6.5 \mathrm{~Hz}$, pyrazoline ring), 4.45 (q, $2 \mathrm{H}, J=8.5 \mathrm{~Hz}, \mathrm{~N}-\mathrm{CH}_{2}$ ), $5.12(\mathrm{t}, 1 \mathrm{H}, J=12.5 \mathrm{~Hz}$, pyrazoline ring), 7.16-7.29 (m, 2H, Ar-H), 7.41-7.48 (m, 3H, Ar-H), 7.50-7.55 (m, 2H, Ar-H), 8.10-8.23 (m, 4H, Ar-H, NH), 9.70 (s, $1 \mathrm{H}, \mathrm{Ar}-\mathrm{OH}) ;{ }^{13} \mathrm{C} \mathrm{NMR}\left(\mathrm{CDCl}_{3}\right) \delta / \mathrm{ppm}: 13.73$, 37.98, 41.93, 62.96, 99.07, 108.61, 109.06, 111.14, $117.71,118.38,119.54,120.78,122.63,123.74$, $126.06,126.57,127.26,128.89,131.43,148.96$, 154.79, 155.45, HRMS (ESI): calculated for $\mathrm{C}_{23} \mathrm{H}_{21} \mathrm{ON}_{3} \mathrm{Cl}(\mathrm{M}+\mathrm{H})^{+} 390.11856$, found 390.11876 .

4-Bromo-2-(5-(9-ethyl-9H-carbazol-3-yl)-4,5-

dihydro-1H-pyrazol-3-yl)phenol (5c): White colored solid; Yield (71\%); $\mathrm{R}_{\mathrm{f}}=0.60(6 \%$ ethylacetate in $\mathrm{n}$ hexane);m. p. $183-184^{\circ} \mathrm{C}$; IR $\tilde{v}_{\max } / \mathrm{cm}^{-1}: 3655$ $(\mathrm{OH}), 3225(\mathrm{NH}), 3065(\mathrm{CH}), 1635(\mathrm{C}=\mathrm{N}) ;{ }^{1} \mathrm{H}$ 240 NMR $\left(\mathrm{CDCl}_{3}\right) \delta / \mathrm{ppm}: 1.40(\mathrm{t}, 3 \mathrm{H}, J=7.5 \mathrm{~Hz}$, $\left.\mathrm{CH}_{3}\right), 3.12$ (dd, 1H, J=10.7 Hz \& $5.9 \mathrm{~Hz}$, pyrazoline ring), 3.61 (dd, $1 \mathrm{H}, J=10.7 \& 5.9 \mathrm{~Hz}$, pyrazoline ring), 4.44 (q, $2 \mathrm{H}, J=7.5 \mathrm{~Hz}, \mathrm{~N}-\mathrm{CH}_{2}$ ), $5.14(\mathrm{t}, 1 \mathrm{H}, J=10.7 \mathrm{~Hz}$, pyrazoline ring), 7.11-7.35 (m, 4H, Ar-H), 7.48-7.75 (m, 4H, Ar-H), 8.10(m, 2H, Ar-H), 8.18 (m, 1H, NH), 12.10 (s, 1H, Ar$\mathrm{OH}) ;{ }^{13} \mathrm{C}$ NMR $\left(\mathrm{CDCl}_{3}\right) \delta / \mathrm{ppm}: 14.82,37.55$, $41.68,63.65,108.77,109.23,118.25,118.89$, $119.63,120.68,122.45,122.83,123.26,123.78$, $123.89,125.69, \quad 126.28,129.79,131.80,139.76$, 140.68, 154.10; HRMS (ESI): calculated for $\mathrm{C}_{23} \mathrm{H}_{21} \mathrm{ON}_{3} \mathrm{Br}(\mathrm{M}+\mathrm{H})^{+} 434.0478$, found 434.0485 .

4-Chloro-2-(5-(9-ethyl-9H-carbazol-3-yl)-4,5dihydro-1H-pyrazol-3-yl)-5-methylphenol (5d): White colored solid; Yield (67\%); $\mathrm{R}_{\mathrm{f}}=0.46(6 \%$ ethylacetate in n-hexane);m. p. $138-139^{\circ} \mathrm{C}$; IR $\tilde{v}_{\max } /$ $\mathrm{cm}^{-1}$ : $3650(\mathrm{OH}), 3238(\mathrm{NH}), 3029(\mathrm{CH}), 1650$ $(\mathrm{C}=\mathrm{N}) ;{ }^{1} \mathrm{H} \mathrm{NMR}\left(\mathrm{CDCl}_{3}\right) \delta / \mathrm{ppm}: 1.39(\mathrm{t}, 3 \mathrm{H}$, $\left.J=7.5 \mathrm{~Hz}, \mathrm{CH}_{3}\right), 2.30$ (s, 3H, Ar- $\left.\mathrm{CH}_{3}\right), 3.16$ (dd, $1 \mathrm{H}, J=10.8 \mathrm{~Hz} \& 5.9 \mathrm{~Hz}$, pyrazoline ring), 3.67 (dd, $1 \mathrm{H}, J=10.8 \& 5.9 \mathrm{~Hz}$, pyrazoline ring), 4.45 (q, $2 \mathrm{H}$, $\left.J=7.5 \mathrm{~Hz}, \mathrm{~N}-\mathrm{CH}_{2}\right), 5.12(\mathrm{t}, 1 \mathrm{H}, J=10.8 \mathrm{~Hz}$, pyrazoline ring), 7.24-7.40 (m, 3H, Ar-H), 7.517.75 (m, 4H, Ar-H), 8.10 (m, 2H, Ar-H), 8.25 (m, $1 \mathrm{H}, \mathrm{NH}), 12.15$ (s, 1H, Ar-OH); ${ }^{13} \mathrm{C} \mathrm{NMR}\left(\mathrm{CDCl}_{3}\right)$ $\delta$ / ppm: 13.95, 37.55, 41.68, 63.69, 108.80, 109.23, $117.29,118.78,119.12,120.68,122.65,122.83$, $123.90,124.80,124.95,125.69,126.78,128.79$, 131.80, 139.72, 140.68, 155.25; HRMS (ESI): calculated for $\mathrm{C}_{24} \mathrm{H}_{23} \mathrm{ON}_{3} \mathrm{Cl} \quad(\mathrm{M}+\mathrm{H})^{+} 403.12514$, found 403.12516 .

2-(5-(9-Ethyl-9H-carbazol-3-yl)-4,5-dihydro1H-pyrazol-3-yl)-5-methoxyphenol (5e): White colored solid; Yield $(68 \%) ; \quad \mathrm{R}_{\mathrm{f}}=0.55(6 \%$ ethylacetate in n-hexane);m. p. $121-122^{\circ} \mathrm{C}$; IR $\tilde{\mathrm{v}}_{\max } /$ $\mathrm{cm}^{-1}$ : $3325(\mathrm{OH}), 3056(\mathrm{NH}), 2973(\mathrm{CH}), 1678$ $(\mathrm{C}=\mathrm{N}) ;{ }^{1} \mathrm{H}$ NMR $\left(\mathrm{CDCl}_{3}\right) \delta / \mathrm{ppm}: 1.36(\mathrm{t}, 3 \mathrm{H}$, $\left.J=8.8 \mathrm{~Hz}, \mathrm{CH}_{3}\right), 3.18(\mathrm{dd}, 1 \mathrm{H}, J=13.3 \mathrm{~Hz} \& 7.4 \mathrm{~Hz}$, pyrazoline ring), $3.33\left(\mathrm{~s}, 3 \mathrm{H}, \mathrm{Ar}-\mathrm{OCH}_{3}\right), 3.65$ (dd, $1 \mathrm{H}, J=13.3 \& 7.4 \mathrm{~Hz}$, pyrazoline ring), 4.43 (q, $2 \mathrm{H}$, $\left.J=8.8 \mathrm{~Hz}, \mathrm{~N}-\mathrm{CH}_{2}\right), 5.14 \quad(\mathrm{t}, 1 \mathrm{H}, J=13.3 \mathrm{~Hz}$, pyrazoline ring), 7.16-7.21 (m, 2H, Ar-H), 7.337.45 (m, 3H, Ar-H), 7.47-7.55 (m, 3H, Ar-H), 8.04$8.10(\mathrm{~m}, 2 \mathrm{H}, \mathrm{ArH}), 8.13$ (s, 1H, NH), 12.00 (s, 1H, Ar-OH $) ;{ }^{13} \mathrm{C}$ NMR $\left(\mathrm{CDCl}_{3}\right) \delta / \mathrm{ppm}: 13.96,37.98$, $44.77,63.41,68.08, \quad 107.94,110.03,117.48$, $120.24,121.22,122.10,123.30,123.76,125.39$, $125.61,126.57,127.00,128.47,128.90,129.35$, 140.53, 141.95, 149.41, 157.31; HRMS (ESI): calculated for $\mathrm{C}_{24} \mathrm{H}_{24} \mathrm{O}_{2} \mathrm{~N}_{3}(\mathrm{M}+\mathrm{H})^{+} 386$. 1904, found 386.1908 .

Acknowledgement: $V . A$. K. is grateful to UGC, WRO, Pune for providing a teacher fellowship under the Faculty development programme of the 
V. A. Kadnor, S. N. Shelke: Synthesis, antimicrobial and antimalarial activity of 1, 4-benzothiazepine and ...

$U G C$ 's $12^{\text {th }}$ plan. The authors are also grateful to the Principal of ACS College, Satral and SSGM College, Kopargaon for providing the necessary facilities and SAIF, University of Punjab, Chandigarh for providing the characterization.

View supporting data here

\section{REFERENCES}

1. K. Thevissen, A. Marchand, P. Chaltin, E. M. K. Meert, B. P. A. Cammue, Curr. Med. Chem., 16, 2205 (2009).

2. M. M. Rahman, A. I. Gray, Phytochemistry, 66, 1601 (2005).

3. I. J. Kang, L. W. Wang, S. J. Hsu, C. C. Lee, Y. C. Lee, Y. S. Wu, A. Yueh, J. C. Wang, T. A. Hsu, Y. S. Chao, J. H. Chern, Bioorg. Med. Chem. Lett., 19, 6063 (2009).

4. C. Yenjai, S. Sripontan, P. Sriprajun, P. Kittakoop, A. Jintasirikul, M. Tanticharoen, Y. Thebtaranonth, Planta Med., 66, 277 (2000).

5. H. Knolker, K. Reddy, Chem. Rev., 102, 4303 (2002).

6. A. Gluszynska, Eur. J. Med. Chem., 94, 405 (2015).

7. B. P. Bandgar, L. K. Adsul, S. V. Lonikar, H. V. Chavan, S. N. Shringare, S. A. Patil, S. S. Jalde, B. A. Koti, N. A. Dhole, R. N. Gacche, A. Shirfule, J. Enzyme Inhib. Med.Chem.,28(3), 593(2013).

8. A. R. Nixha, M. Arslan, Y. Atalay, N. Gencer, A. Ergün, O. Arslan, J. Enzyme Inhib. Med. Chem., 28(4), 808 (2013).

9. H. J. Bo Hrisc, H. Faltz, M. Patzel, J. Liebsc Her, Tetrahedron, 50, 1070 (1994).

10. G. De Sarro, A. Chimirri, A. De Sarro, R. Gitto, S. Grasso, M. Zappala, Eur. J. Med. Chem.,30, 925 (1995).

11. D. Kantoci, E. D. Murray, D. D. Quiggle, W. J. Wechter, J. Med. Chem., 39, 1196 (1996).

12. J. F. F. Liegeois, F. A. Rogister, J. Bruhwyler, J. Damas, T. P. Nguyen, M. O. Inarejos, E. M. G. Chleide, M. G. A. Mercier, J. E. Delarge, J. Med. Chem., 37, 519 (1994).

13. S. V. Karthikeyan, S. Perumal, Tetrahedron Lett., 1, 2261 (2007)

14. U. C. Pant, A. Dandia, H. Chandra, S. Goyal, S. Pant, Phosphorus, Sulfur, Silicon, Relat. Elem., 180, 559 (2005).

15. I. V. Patricio, M. Raquel, M. D. Ivorra, M. P. D’Ocon, B. K. Assels, J. Nat. Prod., 66, 954 (2003).
16. J. B. Bariwal, K. D. Upadhyay, A. T. Manvar, J. C. Trivedi,J. S. Singh, K. S. Jain, A. K. Shah, Eur. J. Med. Chem., 43, 2279 (2008).

17. K. Arya, A. Dandia, Med. Chem., 18, 114 (2008).

18. F. Shi, Z. Xiao-Ning, C. Xu-Dong, Z. Shu, J. Bo, Z. Wei-Fa, T. Shu-Jiang, Bioorg. Med. Chem. Lett., 22, 743 (2012).

19. A. Rahman, A. A. Siddiqui, Int. J. Pharm. Sci. Drug Res., 2, 165 (2010).

20. P. M. Sivakumar, S. Ganesan, P. Veluchamy, M. Doble., Chem. Biol. Drug Des., 76, 407 (2010).

21. P. M. Sivakumar, S. Prabhu Seenivasan, V. Kumar, M. Doble, Bioorg. Med. Chem. Lett., 20, 3169 (2010).

22. P. K. Sharma, S. Kumar, P. Kumar, Eur. J. Med. Chem., 45, 2650 (2010).

23. B. N. Acharya, D. Saraswat, A. K. Shrivastava, R. Ghorpade, S. Bapna, M. P. Kaushik, Eur. J. Med. Chem., 45,430 (2009).

24. A. K Pandey, S. Sharma, M. Pandey, M. M. Alam, M. Shaquiquzzaman, M. Akhter, Eur. J. Med.Chem.,123, 476 (2016).

25. E. Bansal, V. K. Srivastava, A. Kumar, Eur. J. Med. Chem.,36, 81 (2001).

26. T. S. Jeong, K. S. Kim, J. R. Kim, K. H. Cho, S. Lee, W. Lee, Bioorg. Med. Chem. Lett., 14, 2719 (2004).

27. B. P. Bandgar, L. K. Adsul, H. V. Chavan, S. S. Jalde, S. N. Shringare, R. Shaikh, R. J. Meshram, R. N. Gacche, V. Masand, Bioorg. Med. Chem. Lett., 22, 5839 (2012).

28. S. N. Shelke, G. R. Mhaske, S. Gadakh, C. Gill, Bioorg. Med. Chem. Lett., 24(20), 7200 (2010).

29. S. N. Shelke, G. R. Mhaske, D. B. Bonifacio Vasco, M. Gawande, Bioorg. Med. Chem. Lett., 17(22), 5727 (2012).

30. P. S. Kalsi, Spectroscopy of Organic Compounds, $6^{\text {th }}$ edn., New Age International Publishers, New Delhi, 2010, p. 282.

31. A. P. Keche, G. D. Hatnapure, R.T. Tale, A. H. Rodge, S. S. Birajdar, V. M. Kamble,Med. Chem. Res., 22, 14(2013).

32. M. A. Patel, V. G. Bhila, N. H. Patel, A. K. Patel, D. I. Brahmbhatt, Med. Chem. Res., 21, 4381 (2012).

33. K. H. Reickmann, G. H. Campbell, L. J. Sax, J. E. Mrema, Lancet, 1, 221(1978).

34. J. J. S. B. Singh, Indian J.Malariology, 10, 117(1956). 